\title{
Mechanochemical synthesis of carbon-based nanocomposites for supercapacitors
}

\author{
Yuliya G. Mateyshina ${ }^{1,3}$, Artem S. Ulihin ${ }^{1}$ and Nikolai F. Uvarov ${ }^{1,2,3}$ \\ ${ }^{1}$ Institut of Solid State Chemistry and Mechanochemistry, 630128 Kutateladze, 18, Novosibirsk, \\ Russia \\ ${ }^{2}$ Novosibirsk State Technical University, 630073, Prospekt Karla Marksa, 20, Russia \\ ${ }^{3}$ Novosibirsk State University, 630090 Pirogova, 2, Novosibirsk, Russia
}

\begin{abstract}
New nanoporous carbon- $\mathrm{SiO}_{2}$ composite materials were synthesized from organic raw materials (rice shells) and their electrochemical properties were investigated by cyclic voltammetry in liquid electrolytes $\left(6 \mathrm{M} \mathrm{KOH}\right.$ or $\left.1 \mathrm{M} \mathrm{H}_{2} \mathrm{SO}_{4}\right)$. A correlation between specific capacitance and specific surface area was observed. Due to high specific capacitance of $90 \mathrm{~F} / \mathrm{g}$ the carbon materials under study may be regarded as promising electrode materials for electrochemical supercapacitors.
\end{abstract}

\section{Introduction}

Supercapacitors are one of the promising devices for energy storage applications as they can provide higher power density than batteries and higher energy density than conventional dielectric capacitors. Many materials have been proposed as electrode materials for supercapacitors. Among them, carbon materials with various microtextures are considered as main candidates for supercapacitors in terms of high surface area, interconnected pore structure, controlled pore size, high electrical conductivity and environmental friendliness [1-6]. The specific capacitance of the electrode material of the Electrochemical Double Layer Capacitors (EDLC) is known to depend on the specific surface area $\left(\mathrm{S}_{\mathrm{s}}\right)$ and the pore structure [7]. Highly porous carbon materials with high content of mesopores may be obtained from different templates, like metal carbides (by metal etching), various polymers (obtained from micelle solutions followed by carbonization and activation), mesoporous silica or mesoporous molecular sieves, such as MCM-41, MCM-48, SBA-15 [7-14] and some other templates [15]. Nevertheless, as a rule, such materials do not fit with requirements of commercial applications because of their complicated preparation techniques and a relatively high cost [16]. On the contrary, activated carbons are materials most commonly used in supercapacitors because of their high surface areas $\left(\mathrm{S}_{\mathrm{s}} \geq 1000 \mathrm{~m}^{2} / \mathrm{g}\right)$, good adhesion to electrolytes and low cost. Activated carbons can be derived from natural materials (plant shells [17], peel [18, 19], etc.) or synthetic materials (polymers) by carbonization in inert atmosphere followed by activation with $\mathrm{KOH} / \mathrm{NaOH}, \mathrm{K}_{2} \mathrm{CO}_{3}, \mathrm{ZnCl}_{2}, \mathrm{H}_{3} \mathrm{PO}_{4}$, $\mathrm{CO}_{2}$ or steam [20-28]. Although the activation after carbonization increases the $\mathrm{S}_{\mathrm{s}}$ of the carbons, it leads to widening of the pore size distribution and lowering of the product yield. Therefore, synthesis of

This is an Open Access article distributed under the terms of the Creative Commons Attribution License 4.0, which permits unrestricted use, distribution, and reproduction in any medium, provided the original work is properly cited. 
carbon materials with suitable pore size distribution via simple and low-cost root may open possibilities for a wide application of the activated carbons in EDLCs. The use of carbon-based nanocomposites as precursors possesses a possible way to improve performance of carbon electrode materials. Rice husks $(\mathrm{RH})$, a large-scale agricultural waste, is an example of such precursor, which practically has no any commercial application. RH includes high amount of amorphous silica nanosized particles (15-23 wt $\%$ ) [18], that allows one to use as a template-containing precursor for preparation of porous carbons. The aim of this work was to synthesize carbon- $\mathrm{SiO}_{2}$ composites from organic raw precursor (rice husks), to obtain mesoporous carbon electrode materials and to study their electrochemical properties in different electrolytes.

\section{Experimental}

The standard party of the rice husks (RH) was supplied by Kyzylorda Agroservis Co., Kazakhstan. RP contained $36 \mathrm{wt} \%$ of cellulose and $21 \%$ of ash content (mainly $\mathrm{SiO}_{2}$ ). Other components were determined as lignine (17-23 wt \%), hemicellulose (15-20 wt \%) and moisture (4-8 wt $\%$ ). RP was grinded to particles with size of $\sim 0.1-1 \mathrm{~mm}$ using a roll mill PM-20 produced by ISSCM SB RAS [29].

The first party of $\mathrm{RP}$ (Series A) was placed to $1 \mathrm{M}$ solution of $\mathrm{KOH}$, heated at $100{ }^{\circ} \mathrm{C}$ for $3 \mathrm{~h}$ under rigorous stirring, dried in air, heated in a tube reactor at $300{ }^{\circ} \mathrm{C}$ for $2 \mathrm{~h}$ under $\mathrm{Ar}$ flow. Then the sample was mechanically treated in a AGO-2 planetary ball mill for $5 \mathrm{~min}$ and carbonized at $700^{\circ} \mathrm{C}$ for $3 \mathrm{~h}$ under Ar flow.

The second party of milled RH (B) was pyrolized in a quartz reactor under argon atmosphere for $3 \mathrm{~h}$ at $500{ }^{\circ} \mathrm{C}$. Then the sample was mixed with an equimolar mixture of $\mathrm{Na}_{2} \mathrm{CO}_{3}$ and $\mathrm{K}_{2} \mathrm{CO}_{3}$ powders in a weight ratio of $1: 1$. The mixture was mechanically treated in AGO-2 planetary ball mill for 5 min at the mass ratio of the milled material and balls as 1:15. After the treatment the mixture was put into the quartz tube reactor, heated up to $700^{\circ} \mathrm{C}$ with the rate of $10^{\circ} \mathrm{C} / \mathrm{min}$ and kept under this temperature for $3 \mathrm{~h}$. After cooling, the obtained product was washed by deionized water up to $\mathrm{pH} 7$ and dried overnight at $100^{\circ} \mathrm{C}$.

The specific surface area and the pore size distribution of nanoporous carbon materials (NCMs) were determined from nitrogen adsorption/desorption BET isotherms obtained with a Sorbtometr M Surface Analyzer (Kataron Ltd., Russia). Morphology of carbon materials was studied using a Jeol 2000FX High Resolution Electron Microscope. Electrochemical properties were investigated by a cyclic voltammetry technique using a SMU-2 Meter (CIT Ltd., Novosibirsk, Russia) in symmetric two-electrode cells. Aqueous solutions of sulfuric acid $\left(1 \mathrm{M} \mathrm{H}_{2} \mathrm{SO}_{4}\right)$ and potassium hydroxide $(6 \mathrm{M} \mathrm{KOH})$ were used as electrolytes. Electrodes were prepared by mixing the carbon powder with carbon black in a weight ratio of 80:20 and the mixture was pressed onto a surface of a graphite rod-like electrode support. Typically $10-30 \mathrm{mg}$ of NCMs was deposited on the electrode area of $1 \mathrm{~cm}^{2}$. Two identical electrodes were put together through a separator (film PORP-UFIM Ltd., Russia) soaked with solutions of $\mathrm{H}_{2} \mathrm{SO}_{4}(1 \mathrm{M})$ or $\mathrm{KOH}(6 \mathrm{M})$. Specific capacity (C, F/g) was calculated from cyclic voltammetry curves by formula (1):

$$
C=2 \cdot I \cdot m^{-1} \cdot v^{-1}
$$

where $I$ is average current value (A); $\mathrm{m}$ is the mass of the active electrode material in each electrode $(\mathrm{g})$; $v$ is the potential sweep (V/s); factor 2 takes into account a sequential switching of two identical double layers in the cell. All experiment were carried out at $\mathrm{v}=10 \mathrm{mV} / \mathrm{s}$.

\section{Results and discussion}

The properties of the carbon materials obtained by the two methods strongly differ: The values of the specific surface area $\left(S_{\mathrm{s}}\right)$ were determined as 152 and $1020 \mathrm{~m}^{2} / \mathrm{g}$ for samples of Series 1 and 2, respectively. The second sample has much higher values of $S_{\mathrm{s}}$ and the most part of the overall surface 


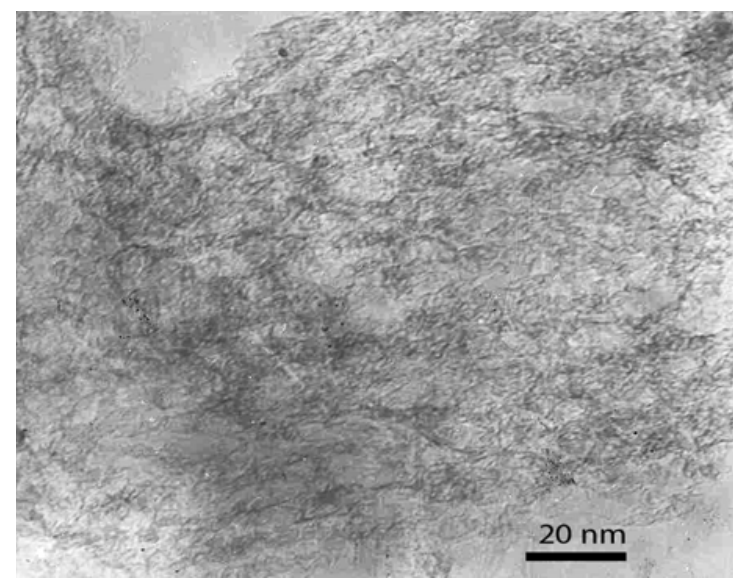

Figure 1. Electron microscopy image of samples of Series B.

formed by micropores with the total volume of $0.49 \mathrm{~cm}^{3} / \mathrm{g}$ and the average size of $\sim 1.2 \mathrm{~nm}$. These data agree well with the results obtained by High-Resolution Electron Microscopy (Fig. 1).

Cyclic volammetry curves obtained for the samples are presented in Fig. 2. One can see that values of specific capacitance and the character of A-B-curves depend on the electrolyte type $(6 \mathrm{M} \mathrm{KOH}$ or $1 \mathrm{M} \mathrm{H}_{2} \mathrm{SO}_{4}$ ). The capacity values obtained in alkaline electrolytes are 1.5-2 times lower. This fact is in agreement with the data reported in literature: Generally, specific capacity values measured in acid electrolytes are higher then those obtained in alkali electrolytes [30]. Moreover, in acid electrolyte a small additive pseudo-capacitance effect is also observed for all samples. Specific capacitance values are relatively high $(25-90 \mathrm{~F} / \mathrm{g})$, and attributed mostly to double layer capacitance.

The data obtained may be compared with the data reported in literature. According to data reported earlier [31] the specific surface capacitance (C) of carbon materials does not depend on the average pore size and the type of carbon material. In this case the $\mathrm{C}$ value should increase proportionally to the specific surface area [32]:

$$
C(F / g)=0.094 \cdot S\left(m^{2} / g\right)
$$

Comparison shows that the experimental value of $\mathrm{C}$ for the sample of Series A and B obtained in acidic electrolyte (25 and $90 \mathrm{~F} / \mathrm{g}$ ) agrees satisfactorily with the expected value (14 and $96 \mathrm{~F} / \mathrm{g}$ ).

\section{Conclusion}

In this work a simple technique for synthesis of mesoporous carbon materials from natural $\mathrm{RH}$ was proposed. The technique includes preliminary mechanical treatment of RP with alkali carbonates followed by carbonization and washing the product of silicates. As a result of the study, it may be concluded that RP may be used as an effective and cheap natural green source for synthesis of carbon electrode materials for EDLCs. The presence of considerable amount of silica nanoparticles in the bulk of RH provides using this matrix as a template precursor for preparation of the mesoporous carbon. The obtained materials have high specific surface area and high specific capacitance that make them attractive for commercial applications. 

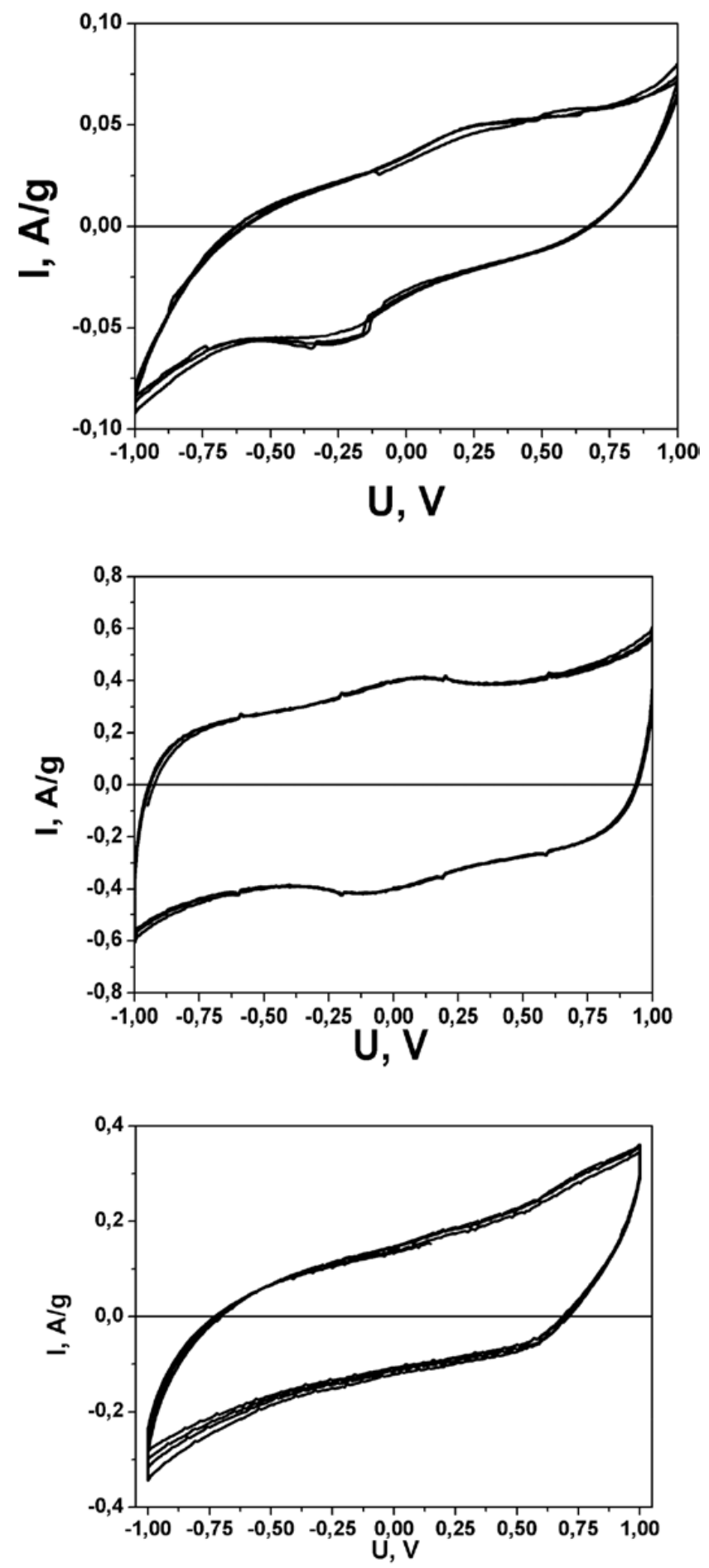

Figure 2. Cyclic voltammogram of the samples of Series A and B in $1 \mathrm{M} \mathrm{H}_{2} \mathrm{SO}_{4}$ electrolyte, Series $\mathrm{B}$ in $6 \mathrm{M} \mathrm{KOH}$, 1,2 and 3 respectively; voltage sweep rate is $10 \mathrm{mV} / \mathrm{s}$. 
$3^{\text {rd }}$ European Energy Conference

\section{References}

[1] Zh. Zheng, Q. Gao, J. Power Sources, 196, 1615-1619 (2011)

[2] I. Muylaert, A. Verberckmoes, J. De Decker, P. Van Der Voort, Adv. in Colloid and Interface Sc., 175, 39-51 (2012)

[3] H. Jiang, P. S. Lee, Ch. Li, Energy Environ. Sci., 6, 41-53 (2013)

[4] R. Dash, J. Chmiola, G. Yushin, Y. Gogotsi, G. Laudisio, J. Singer, et al., Carbon, 44, 2489-2497 (2006)

[5] K. Xia, Q. Gao, J. Jiang, J. Hu, Carbon, 46, 1718-1726 (2008)

[6] M. Kaempgen, C.K. Chan, J. Ma, Y. Cui, G. Gruner, Nano Lett., 9, 1872-1876 (2009)

[7] J. Chmiola, G. Yushin, Y. Gogotsi, C. Portet, P. Simon, P.L. Taberna, Science 313, 1760-1763 (2006)

[8] D.P. Xu, S.-H. Yoon, I. Mochida, W.M. Qiao, Y.G. Wang, L.C. Ling, Micropor. Mesopor. ater., 115, 461-468 (2008)

[9] A. Vantomme, L. Surahy, B.L. Su, Colloids Surf. A: Physicochem. Eng. Aspects, 300, 65-69 (2007)

[10] S.H. Joo, Ch. Pak, D.J. You, S.-A. Lee, H.I. Lee, J.M. Kim, H. Chang, D. Seung, Electrochim. Acta, 52, 1618-1626 (2006)

[11] M. Sevilla, S. Álvarez, T.A. Centeno, A.B. Fuertes, F. Stoeckli, Electrochim. Acta, 52, 3207-3215 (2007)

[12] S. Alvarez, A.B. Fuertes, Carbon, 42, 433-436 (2004)

[13] W. Xing, P. Bai, Z.F. Li, R.J. Yu, Z.F. Yan, G.Q. Lu, L.M. Lu, Electrochim. Acta, 51, 4626-4633 (2006)

[14] C.H.-H. Pak, H. Chang, J.-M. Kim, US Patent 7, 220, 697 (2007)

[15] G.V. Plaksin, V.F. Surovikin, V.B. Fenelonov, V.A. Semikolenov, L.G. Okkel', Kinetika i Kataliz, 34, 1079-1083 (1993)

[16] E. Raymundo-Pinero, M. Cadek, F. Béguin, Adv. Funct. Mater., 19, 1032-1039 (2009)

[17] D. Adinata, W.M.A. Wan Daud , M.Kh. Aroua, Bioresource Technology, 98, 145-149 (2007)

[18] K.Y. Foo, B.H. Hameed, J. Chemical Engineering, 180, 66- 74 (2012)

[19] K.Y. Foo, B.H. Hameed, Bioresource Technology, 102, 9814-9817 (2011)

[20] Y. Meng, D. Gu, F.Q. Zhang, Y.F. Shi, H.F. Yang, Z. Li, et al., Angew Chem Int Ed, 44 (2005)

[21] F.H. Simanjuntak, J. Jin, N. Nishiyama, Y. Egashira, K. Ueyama, Carbon, 47 (2009)

[22] J. Jin, N. Nishiyama, Y. Egashira, K. Ueyama, Microporous Mesoporous Mater, 118 (2009)

[23] Y.H. Deng, T. Yu, Y. Wan, Y.F. Shi, Y. Meng, D. Gu, et al. J Am Chem Soc, 129 (2007)

[24] J. Guo, A.C.H. Lua, J. Colloid Interface Sci., 254, 227-233 (2002)

[25] P.M. Eletskii, V.A. Yakovlev, V.B. Fenelonov, V.N. Parmon, Kinet. Catal., 49, 708-719 (2008)

[26] Y. Guo, K. Yu, Z. Wang, H. Xu, Carbon, 41, 1645-1647 (2003)

[27] M.A. Lillo-Ródenas, D. Cazorla-Amorós, A. Linares-Solano, Carbon, 41, 267-275 (2003)

[28] H. Marsh, D. Crawford, T.M. O'Grandy, A. Wennerberg, Carbon, 20, 137-138 (1982)

[29] E.G. Shapolova, A.L. Bychkov, O.I. Lomovsky, Chem. for Sustainable Development, 20, 639644 (2012)

[30] E.G. Bushueva, P.S. Galkin1, A.V. Okotrub, L.G. Bulusheva, N.N. Gavrilov, V.L. Kuznetsov, S.I. Moiseekov, Phys. Stat. Sol., 245, 10, 2296-2299 (2008)

[31] T.A. Centeno, O. Sereda, F. Stoeckli, Phys. Chem. Chem. Phys., 13, 12403 (2011)

[32] Yu. Mateyshinaa, A. Ulihin, A. Samarov, Ch. Barnakov, N. Uvarov, Solid State Ionics, 251, 59-61 (2013) 